\title{
Pseudoxanthoma elasticum
}

\author{
INSERM
}

\section{Source}

INSERM. (1999). Orphanet: an online rare disease and orphan drug data base.

Pseudoxanthoma elasticum. ORPHA:758

Pseudoxanthoma elasticum (PXE) is an inherited connective tissue disorder characterized

by progressive calcification and fragmentation of elastic fibers in the skin, retina, and arterial walls. 